\title{
DINAMIKA PEMIKIRAN ISLAM INDONESIA DALAM PERSPEKTIF EPISTEMOLOGI FIQH DAN KONTRIBUSINYA BAGI PENEGUHAN SEMANGAT KEBANGSAAN DAN KEINDONESIAAN
}

\author{
Fathorrahman Ghufron* \\ fathur_2000@yahoo.com
}

\begin{abstract}
This paper will examine the epistemology of Islamic jurisprudence from the perspective of which the dynamics of Islamic thought since the beginning of independence era until the reform era is understood. Through the three aspects of epistemology, i.e. Bayāni, Ta'līi, and Istișlāhi, the author tries to analyze the different ways of view and the characteristics of thoughts between each group in expressing their Islamic thinking. It found out that the diversity of thoughts which go along with the dynamics of Islamic thinking has also an impact on the construction of strengthening nationality and Indonesia-ness.
\end{abstract}

Keywords: Dynamics of Thought, Epistemology of Figh, Indonesia-ness

Abstrak

Tulisan ini mendeskripsikan epistemology fikih sebagai sebuah perspektif dalam menjelaskan bagaimana dinamika pemikiran Islam yang berlangsung sejak awal-awal kemerdekaan hingga era reformasi. Melalui epistemologi yang terangkum dalam tiga aspek, yaitu Bayani, Ta'lili, dan Istislahi penulis mencoba menganalisis bagaimana perbedaan cara pandang dan ciri berfikir dari masing-masing kelompok dalam mengekspresikan pemikiran keislamannya. Dari hasil analisis tersebut, penulis menemukan bahwa keragaman cara pandang yang beririsan dengan dinamika pemikiran keislaman berpengaruh pula terhadap konstruksi peneguhan kebangsaan dan keindonesiaan.

Kata Kunci: Dinamika Pemikiran, Epistemologi Fikih, Ke-Indonesia-an

\section{PENDAHULUAN}

Indonesia merupakan negara yang berciri keberagaman dalam kesatuan (diversity in unity) yang kemudian dikenal sebagai semboyan "Bhinneka Tunggal Ika". / Potretl Juhur/ini tidak hadir dalam ruang hampa yang sertamerta diturunkan dari langit. Akan tetapi, ada proses panjang di mana masing-masing pihak terlibat dalam perbenturan pandangan dan wacana kajian yang dilatari oleh aneka ragam pemikiran.

Masing-masing pemikiran yang diajukan oleh para pemangku kepentingan membentuk sebuah ideologi yang di kemudian hari bermetamorfosis sebagai pergerakan. Dari pergerakan ini lah, pemikiran yang dilesatkan ke ruang publik membentuk sebuah dinamika yang satu sisi diamini sebagai pengetahuan

*Dosen Fakultas Shari'ah dan Hukum, UIN Sunan Kalijaga Yogyakarta yang lazim diikuti maupun sebagai kontroversi yang selalu terbuka untuk diperdebatkan.

Hal ini sebagaimana yang kentara dalam pemikiran Agus Salim bahwa Islam adalah prinsip utama yang bisa dijadikan sebagai pedoman untuk mengatasi pelbagai persoalan dalam kehidupan masyarakat. Upaya memperoleh dukungan dan pengakuan bagi perjuangan Islam menuntut penciptaan kerangka solidaritas kolektif dan ideology pemikiran. Maka, Serikat Islam (SI) yang dibangun Tjokroaminoto namun nuansa pergerakan keislamannya dieksplisitkan oleh Agus Salim mulai mempertautkan afiliasinya bersama gerakan Pan Islam. ${ }^{1}$

Namun demikian, corak Islamisme yang ditegaskan oleh Agus Salim berhadapan dengan figur lain yang justru bersikeras untuk

${ }^{1}$ Suradi SS, Grand Old Man of The Republic Haji Agus Salim dan Konflik Politik Dalam Sarekat Islam (Yogyakarta, Mata padi presindo, 2014), hlm. 100-110. 
memisahkan perkara agama dari negara maupun kebiasaan masyarakat yang memanifestasikan nilai-nilai tradisi. Kehadiran Soekarno sebagai representasi tokoh muda yang terinspirasi pengalaman Turki memberikan pandangan berbeda bahwa Indonesia harus ditampilkan sebagai negara yang tidak patut dimonopoli oleh corak pemikiran tertentu yang berafiliasi pada ideologi keagamaan seperti Islam. ${ }^{2}$

Bersama kelompok Nasionalis sekuler, Soekarno berupaya merumuskan pemikiran yang dianggap memadai dengan iklim Indonesia melalui konsep kebangsaan yang satu sisi tidak menonjolkan semangat keummat-an di bawah naungan agama tertentu, dan di sisi lain menegaskan spirit kewargaan yang bisa menaungi semua pihak yang terdiri dari lintas batas keagamaan, kesukuan, dan ikatan kohesi sosial lainnya.

Dampaknya, dalam setiap perundingan yang dilakukan para punggawa kemerdekaan Indonesia tersebut selalu mempertemukan corak pemikiran yang dinamis sesuai dengan cara pandang dan cara berfikirnya. Salah satu contoh menarik yang pernah terjadi dalam sejarah keindonesiaan ketika semua pihak terlibat dalam perdebatan sengit untuk menentukan dasar negara Indonesia.

Dalam kaitan ini, Pancasila yang terdiri dari lima sila sebagai dasar Negara Indonesia merupakan hasil dari dinamikal pemikiran antar kelompok nasionalis sekuler (nasionalis yang netral agama) dan nasionalis muslim yang saling mengemukakan pandangan dan pendapatnya di dalam BPUPKI.Bahkan di tubuh muslim sendiri, silang pendapat sangat runcing antara mencantumkan kalimat tambahan "penerapan syariah bagi pemeluknya" di sila pertama atau menyederhanakan bunyi kalimat "ketuhanan yang maha esa" yang implikasinya dapat dirasakan oleh semua pemeluk agama. ${ }^{3}$

Keberadaan Muhammad Hatta yang ditunjuk Soekarno untuk mewakili kelompok

${ }^{2}$ Abdulloh Shodiq, Sekulerisme Soekarno dan Mustafa Kemal (Pasuruan: PT. Garoeda Buana Indah, 1994), hlm. 75-78.

${ }^{3 \mathrm{Y}}$ udi Latif, Negara Paripurna: Historisitas, Rasionalitas dan Aktualitas Pancasila, (Jakarta, Gramedia, 2011), hlm. 150-180 nasionalis Muslim menjadi faktor penentu untuk melahirkan rumusan sila dasar negara yang bisa diterima semua kalangan umat beragama. Bahkan, kehadiran Wahid Hasyim dalam perundingan itu mendukung argument Muhammad Hatta untuk menerakan kata "Tuhan" sebagai kata "Allah" di sila pertama Pancasila kian memperkuat pentingnya nilainilai netral-universal yang bisa menaungi semua pihak yang hidup di Indonesia dengan aneka ragam keyakinan dan kepercayaan agamanya. ${ }^{4}$ Alasan mengapa di dalam Pancasila tidak mencantumkan asas keyakinan agama tertentu disebabkan oleh kesadaran transendental para punggawa kemerdekaan bahwa Indonesia terdiri dari beragam suku dan agama yang juga terlibat aktif dalam perlawanan dan mempertahankan kedaulatan Indonesia.

Sekuel sejarah tentang bagaimana Pancasila yang diperdebatkan model representasinya oleh sekelompok beragama, terutama yang menganut ajaran Islam, menjadi bukti betapa dinamika pemikiran terjadi saat itu. Bahkan, dinamika pemikiran tersebut masih berlangsung hingga kini, yang terus berupaya keras untuk menjadikan ajaran Islam sebagai raison d'tre asas kehidupan bernegara di Indonesia.

Apalagi, Indonesia memasuki sebuah era reformasiyangsaratdengansuasanademokrasi, dimana I setiap Sihak bebas menyuarakan aspirasinya melalui pergerakan personal maupun jaringan institusonal. Di era reformasi ini, negara nyaris tak memiliki kewenangan penuh untuk membatasi pergerakan setiap warga yang ingin menyuarakan kebebasan pendapatnya. Sebab, di era ini setiap tindaktanduk warga akan dikawal oleh lensa hak asasi yang siap melindungi bila memperoleh perlakuan tidak adil dari negara. Implikasinya, asas negara seperti Pancasila dan UUD 45 yang menjadi landasan konstitusinya selalu dipersoalkan oleh sekelompok orang yang tergabung dalam barisan kelompok "kanan"

${ }^{4}$ Einar Martahan Sitompul, NU dan Pancasila, (Yogyakarta: LKiS, 2010), hlm. 175 
yang selama ini sangat eksklusif dan fanatik dengan kebenaran ajaran agamanya.

Potret perlawanan terhadap Pancasila sebagaimana dilakukan oleh beberapa kelompok seperti Majelis Mujahidin dan Kelompok Penyiapan Penerapan Syariat Islam (KPPSI) menginginkan Indonesia berada dalam pengaruh ajaran agama Islam. ${ }^{5}$ Namun demikian, meskipun negara nyaris tersekap dalam ketidakberdayaan dalam menangani fenomena ini, bukan berarti kelompok-kelompok kanan ini memiliki kebebasan penuh untuk mengindoktrinasikan berbagai jenis ajaran dan pergerakannya. Justru, berbagai kelompok agama yang mewarisi keluhuran dan kearifan ulama panutan kelompoknya yang beraliran moderat seperti Nahdlatul Ulama (NU) dan Muhammadiyah, menjadi garda terdepan pula untuk mempertahankan Pancasila sebagai dasar Negara dan UUD 45 sebagai landasan konstitusinya.

Seolah terjadi pengulangan sejarah, di mana berbagai ulama pendiri NU dan Muhammadiyah yang terlibat aktif dalam menegaskan semangat kemoderasian (wașatiyyah) dalam melahirkan dasar negara yang bersifat netraluniversal bagi bangunan kebangsaan dan keindonesiaan, beberapa generasi kelompok NU dan Muhammadiyah saat ini masih setia mengimplementasikan apa yang menjadi warisan pendahulunya.

Berangkat dari rentetan Esejarah/ini, negara Indonesia yang kini diperkuat dengan semboyan "bhinneka tunggal ika" dan di dalamnya terdapat Jumlah penduduk 350 juta jiwa yang $85 \%$ mayoritas muslim menyebar dalam berbagai kelompok baik yang dilandasi oleh semangat etnisitas (tribalism), garis keturunan (trah), organisasi kemasyarakatan (cultural ideology), hingga organisasi politik (arus kepentingan), salah satu mutu manikam yang sangat berpengaruh dan berlangsung secara dialektik adalah adanya dinamika pemikiran Islam.

${ }^{5}$ Haedar Nashir, Islam Syariat: Reproduksi Salafiyah Ideologis di Indonesia, (Bandung: Mizan, 2013), hlm. 250-300.
Dalam dinamika pemikiran Islam ini, merujuk pada studi Yudi Latif termuat sebuah identitas kemusliman yang memiliki dua penanda (signifier) ${ }^{6}$ yaitu pertama, kemusliman yang merujuk pada aktifitas kesalehan dalam beragama di ruang privat. Dalam penanda ini, setiap muslim lebih memfokuskan diri pada ekspresi peribadatan yang bersifat ritualistik untuk menuju pada semangat spiritualistik. Berbagai kegiatan ('amaliyyah) seperti mujahadah, tarekat maupun seremonial lain yang berkait dengan momentum keislaman seperti mauludan, isra' mi'raj, dan lain sebagainya menjadi sarana peringatan (tadhkirah) untuk meningkatkan diri sebagai pribadi yang senantiasa dekat (taqarrub) kepada Allah Swt.

Kedua, kemusliman yang merujuk pada tradisi-tradisi politik dan intelektual yang dibangun melalui praktik pewacanaan (diskursus) ajaran keislaman di ruang publik. Dalam wilayah ini, setiap muslim terlibat dalam kelompok perserikatan yang menegaskan cara pandang dan model pemahamannya terhadap ajaran Islam baik yang bersumber pada al-Qur'an, Hadis, maupun fikih yang berafiliasi pada ulama-ulama yang dipandang mumpuni sebagai suri keteladanan dalam memanifestasikan nilai-nilai kebenaran yang termuat dalam beberapa sumber naqliyah di atas. Dalam penanda kedua ini, dinamika cemikiran/ Islam Tdiwarnai oleh serapan pemahaman dan penafsiran (interpretative understanding) terhadap berbagai sumber naqliyah maupun literature kajian ulama yang diyakini sebagai model transformasi dan produksi pengetahuan keagamaan.

Serapan pemahaman ini diformulasi dalam aneka ragam pergerakan yang dinamis yang menurut Deliar Noer terbagi dalam dua model yaitu gerakan tradisional dan gerakan modern yang terdiri dari gerakan sosial di satu sisi dan gerakan politik di sisi yang lain. ${ }^{7}$ Dalam perkembangannya, dua model gerakan

${ }^{6} Y$ udi latif, Intelegensia Muslim dan Kuasa, (Bandung: Mizan, 2003), hlm. 78-80.

${ }^{7}$ Deliar Noer, Gerakan Modern Islam di Indonesia 1900-1942, (Jakarta: LP3ES, 1980), hlm. 190-200. 
tersebut bermetamorfosis ke dalam varian gerakan yang lebih sistematis dan masif yaitu, tradisional digubah menjadi neo-tradisionalis atau post tradisionalis yang berhulu kepada arus tradisionalisme ${ }^{8}$

Berbagai adaptasi arus pemikiran keislaman yang dinamis tersebut membentuk sebuah pergulatan pemikiran yang tidak saja mempengaruhi wacana pemikiran keislaman yang bergema di ruang-ruang akademik dan non-akademik, namun juga menuai protes dari berbagai kelompok aliran kanan yang juga melahirkan varian tersendiri seperti neofundamentalisme ${ }^{9}$

Perjumpaan antara neo-tradisionalis, neomodernis, dan neo-fundamentalis di ruang publik membingkai sebuah dinamika pemikiran keislaman yang sampai saat ini selalu hidup bahkan kadang kala bersitegangan manakala masing-masing dari ketiganya mengeksplorasi dan mengenengahkan hasil refleksi pembacaan dan pemahamannya terhadap ajaran Islam.

Pada titik ini, dinamika pemikiran keislaman yang berlangsung hangat di Indonesia tersebut menjadi sumber kajian yang tak habis-habisnya diteliti oleh berbagai kalangan cendekiawan baik dari dalam negeri maupun luar negeri. Sehubungan dengan tumbuh suburnya dinamika pemikiran keislaman di Indonesia, diperlukan beragam cara pandang maupun pendekatan untuk memotret perkembangan dinamika baru yang berlangsung dalam pergulatan pemikiran keislaman Indonesia.

Dalam hal ini, untuk memperluas cakupan cara pandang dan pendekatan dalam memotret dinamika pemikiran Islam Indonesia, tulisan ini mencoba menggunakan analisis lain yang

${ }^{8}$ Zaini Rahman "Post-Tradisionalisme Islam: Epistemologi Peloncat Tangga" dalam Bulletin Wacana Postra, edisi Perkenalan, Nopember, 2001 dan jurnal Tashwirul Afkar yang mengambil topik "Post-Tradisionalisme" sebagai tema sentral isu edisinya-dan neo-modernisme yang berhulu kepada arus modernism-sebagaimana dikupas dalam Ahmad Amir Aziz, Neo-Modernisme Islam Di Indonesia, (Jakarta: Rineka Cipta, 2000), hlm. 97-100.

${ }^{9}$ Adian Husaiani dan Nuim Hidayat dalam "Islam Liberal; Sejarah, Konsepsi, Penyimpangan dan Jawabannya, (Yogyakarta: GIP, 2002), hlm. 60-65. selama ini menjadi basis penelaahan umat Islam-terutama kaum terdidik yang berada di lingkup pesantren dan perguruan tinggi keagamaan-berupa epistemologi fikih.

Alasan mendasar pentingnya penggunaan epistemologi fikih dalam mencermati dinamika pemikiran Islam yang sejak dahulu tumbuh dan berkembang hingga saat ini, dikarenakan fikih itu sendiri telah menjadi sebuah primadona kajian keislaman yang sudah berlangsung berabad lamanya dan diakui sebagai jalan pembuka yang sangat strategis untuk memahami dan mempelajari berbagai butir pengetahuan yang ada dalam ajaran Islam.

Selain itu, melalui epistemologi fikih, penulis mencoba menyingkap sebuah varian lain dari perkembangan pemikiran Islam Indonesia yang selama ini hanya digambarkan dalam tiga gerakan sebagaimana termaktub di atas. Setidaknya, melalui epistemologi fikih, ada upaya reaktualisasi penggalian khazanah keilmuan Islam dari dalam-yang berbasis pada keilmuan syariah-sebagai metode dan pendekatan dalam mengenengahkan sebuah dinamika pemikiran Islam yang selama ini berlangsung dinamis di Indonesia. Di samping itu, penggunaan epistemologi fikih menjadi landasan cara pandang yang berbeda bahwa untuk memahami dinamika pemikiran Islam tidak mesti berangkat dari teori-teori modern melainkan bisa beranjak dari teori keislaman itu sendiri.

Pada titik/ini lah, mozaik pendekatan menjadi terbuka untuk membaca sebuah dinamika sehingga dinamika tersebut tidak hanya dipetakan melalui kaca mata luar. Sebab, disadari atau tidak Indonesia adalah negara yang bermula dari tradisi nusantara, di mana fikih menjadi pengawal pertama bagaimana pemikiran keislaman berkembang dan menyebar ke seluruh penjuru tanah air. Dan, di dalam kajian fikih terdapat mekanisme pengetahuan yang sudah teruji sejak dahulu dalam memetakan sebuah dinamika pemikiran keislaman yang berlangsung dalam tubuh penganutnya. 
EPISTEMOLOGI FIKIH: SEBUAH PEMBACAAN DINAMIKA PEMIKIRAN ISLAM

Dalam kajian fikih, terdapat tiga metode penemukan hukum yang digunakan sebagai cara untuk memetakan kecenderungan berfikir masing-masing kelompok dalam mengkaji, memahami, dan menginterpretasikan sebuah ajaran Islam. Pertama, metode bayānī. Kedua, metode isti'lilì. Ketiga, metode istiṣlāhi. ${ }^{10}$ Ketiga metode ini akan penulis gunakan sebagai alat analisis untuk menjelaskan bagaimana dinamika pemikiran Islam berlangsung di Indonesia.

Pertama, metode bayānī yang menggunakan paradigma tekstualis-skriptualis untuk mendedahkan spirit keislaman berdasarkan pemahaman yang literlek. Metode ini digunakan untuk mereproduksi makna-makna teks yang ada di dalam al-Qur'an dan Hadis tanpa dilibatkan ke dalam kajian sosial-kritis yang dapat memungkinkan bagi lahirnya pemahaman lain dari makna teks yang ada. Metode ini dilakukan atas dasar semangat kehatihatian (ikhtiyāt) yang dilakukan agar terhindar dalam tindakan kekeliruan dalam mengurai inti pesan yang termuat dalam al-Qur'an dan Hadis. ${ }^{11}$

Dalam perkembangannya, metode ini memengaruhi aneka pergerakan kaum Muslim ketika terlibat dalam aneka perserikatan baik dalam konteks organisasi kemasyarakatan (ormas) maupun organisasi politik (orpol). Hadirnya kelompok ormas seperti Majlis Mujahidin ${ }^{12}$, Majlis Tafsir al-Qur'an sebagaimana dalam penelitian Syaifudin Zuhri ${ }^{13}$, Hizbut Tahrir (HTI) ${ }^{14}$ menjadi bukti akademik bahwa dalam pergerakan mereka di Indonesia banyak mengunggulkan ajaran Islam yang

\footnotetext{
${ }^{10}$ Asjmuni A. Rahman, Metode Penetapan Hukum Islam, (Jakarta; Bulan Bintang, 2004), hlm. 50-60.

${ }_{11}$ Amir Syarifuddin, Ushul Fiqih, (Jakarta; PT. Logos Wacana Ilmu, 1997), hlm. 30-45.

${ }^{12}$ Haidar Nashir,Islam Syariat., hlm. 250.

${ }^{13}$ Saifudin Zuhri, "Majelis Tafsir Al Qur'an and its struggle for Islamic reformation". Thesis pada Leiden University.

${ }^{14}$ Saifudin, Khilafah vis a vis Nation state: Telaah atas pemikiran HTI (thesis pada program Pascasarjana UIN Sunan Kalijaga.
}

harus diimplementasikan dalam kehidupan masyarakat.

Dalam proses indoktrinasinya, beberapa kelompok tersebut banyak menggunakan ayatayat al-Qur'an dan Hadis yang berkaitan dengan revivalisasi ajaran Islam yang serta pendapatpendapat ulama seperti Jamaludin al-Afghani, Hasan al-Banna, Muhammad Abduh, Rasyid Ridla Sayyid Qutub yang dianggap sebagai teladan pemikiran keislaman. Bahkan, dalam wacana tandingnya (counter discourse) mereka meragukan berbagai konsep negara bangsa yang melahirka ide demokrasi sebagai jalan menuju kesejahteraan. Terlebih dasar negara Indonesia yang bermuara pada Pancasila dianggap sebagai produk sekuler yang tidak sesuai dengan rakyat Indonesia yang mayoritas beragama Islam. ${ }^{15}$

Untuk memudahkan keinginan peneguhan semangat keberislaman di Indonesia, beberapa kelompok tersebut bersinergi dengan partai politikyang memiliki platform keislaman seperti Partai Keadilan Sejahtera (PKS). Melalui parpol ini, mereka berjuang di level pemerintahan agar semangat keislaman menjadi landasan bernegara bagi masyarakat Indonesia. Setidaknya, mayoritas muslim yang menjadi penduduk negara Indonesia diharapkan bisa menjalankan proses kehidupannya berdasarkan semangat keislamanan yang mereka cita-citakan.

Meskipun pada level pragmatis, PKS harus berafiliasi/kepada parpol lain yang beraliran nasionalis seperti Demokrat-sebagaimana yang terjadi di era kepemerintahan Susilo Bambang Yudoyono-lantaran posisi suaranya tidak/memungkinkan untuk menjadi partai penguasa di republik ini, langkah ini banyak dilakukan demi menggerakkan semangat keberislaman di berbagai level kehidupan masyarakat.

Hasilnya, dalam proses pergerakan perserikatan melalui jalur parpol, metode bayani yang beraksentuasi pada logika tekstualisskriptualis tetap hidup di berbagai arena

${ }^{15}$ Noorhaidi Hasan, Islam Politik di Dunia Kontemporer: Konsep, Geneologi, dan Teori, (Yogyakarta: Suka Press, 2012), hlm. 158. 
kehidupan masyarakat, bahkan lamat-lamat cara pandang mereka mulai merambah ke berbagai sub-sektor keberagamaan di level bawah, seperti di masjid, majlis taklim, dan halaqahhalaqah lainnya yang merevitalisasi semangat keislaman.

Meskipun pada level empiris, pergerakan mereka selalu mendapat perlawanan dari masyarakat sekitar namun perjuangan mereka untuk menyebarkan indoktrinasi keislaman melalui metode bayānī tetap berjalan. Sebab, alasan mendasar yang diyakini oleh mereka adalah semangat keislaman menjadi satusatunya jalan untuk merubah keadaan di Indonesia yang selama banyak dikooptasi oleh kepentingan globalisasi.

Kedua, metode ta'lìi yang menggunakan paradigma analogi (qiyās) untuk mendedahkan spirit keislaman berdasarkan pemahaman yang interkonektif antara dari kasus nash (ușūliyah) ke kasus cabang (furū'iyyah) yang memiliki persamaan alasan (,illat). Dengan kata lain, sebuah kasus yang membutuhkan penemuan hukumnya yang tidak dijumpai jalan penyelesaiannya dalam al-Qur'an maupun Hadis, bisa menggunakan nalar sosial yang bersumber pada nilai-nilai kearifan lain yang berlaku dalam realitas sosial untuk menentukan bentuk hukum barunya.

Melalui metode ini, setiap muslim dirangsang untuk memperluas kajian keislaman tidak sekedar mengeksplorasi makna teks secara literal yang ada dalam al-Quran. Namun, aneka relitas sosial yang bersenyawa dengan nilai-nilai kebenaran sebegaimana di tegaskan dalam ajaran Islam bisa dirumuskan sebuah konsep baru yang satu sisi menegaskan nilainilai keislaman dan di sisi lain menegaskan landasan moralitas yang menjadi keniscayaan dalam realitas sosial.

Konsep tauhid Sosial yang dikemukan oleh Amin Rais, banyak menderivasikan berbagai nilai keluhuran (adi luhung) yang berkaitan dengan etika keislaman yang ditempatkan sebagai basis politik kelembagaan dan sistem maupun perilaku dalam konteks sosial. Dalam konteks tauhid sosial, politik disikapi dalam tiga unsur yaitu, pertama, politik sebagai amanah dan sebagai konsep keagamaan. Kedua, kesadaran akan tanggung jawab politik. Ketiga, keterkaitan politik dengan prinsip ukhuwah yang melampaui batas etnik, ras, agama, dan status sosial ekonomi, budaya dan lainnya ${ }^{16}$

Dalam kaitan ini, pemikiran Amien yang menderivasi semangat keislaman dalam konteks politik ${ }^{17}$ menjadi strategi perjuangan Amien Rais dalam mengimplementasikan ajaran Islam meskipun cara berfikir yang digunakan tidak bermuara pada model pertama di atas, yaitu metode bayānī.

Di samping Amien Rais, terdapat intelektual Muslim lain yang multi talented sebagai sejarawan, budayawan, dan akademisi yang banyak mengelaborasi semangat keislaman dalam cara kerja analogi pemikiran. Adalah Kuntowijoyo yang merumuskan pemikiran keislaman yang kontekstual dengan semangat zaman. Berbagai ayat al-Qur'an dielaborasi dalam bentuk kiasan yang membumi sehingga menghasilkan pemahaman baru tentang nilainilai keislaman. Salah satu ayat populer yang banyak disitir oleh Kuntowijoyo adalah ayat yang berbunyi: kamu adalah ummat yang terbaik yang dilahirkan untuk manusia, menyuruh kepada yang ma'ruf, mencegah dari yang mungkar, dan beriman kepada Allah (QS. al-Imran: 110).

Bagi Kuntowijoyo, ayat ini memiliki struktur transendental sebagai refrensi untuk menafsirkan Rrealitas sosial. Pengandaian struktur transendental ini berkaitan dengan bangunan ide yang transendental, sebuah orde, atau sistem gagasan yang otonom dan sempurna. ${ }^{18}$ Maka, untuk mendedahkan spirit transendental yang berkaitan dengan realitas sosial, ayat tersebut memiliki tiga unsur yang berhubungan dengan semangat humanisasi

${ }^{16}$ Jazim Hamidi, Hermeneutika Hukum, Teori Penemuan Hukum Baru Dengan Interprestasi Teks, (Yogyakarta : UII Pres, 2004), hlm. 115-125.

${ }^{17}$ Amien Rais, Cakrawala Islam: Antara Cita dan Fakta, (Bandung: Mizan, 1987), hlm. 30-35.

${ }^{18}$ Arif Afandi dalam buku Islam Demokrasi Atas Bawah: polemik strategi perjuangan umat model Gus Dur dan Amien Rais, (Yogyakarta: Pustaka Pelajar, 1997), hlm. 60. 
(amar ma'rūf), liberasi (nahy munkar), dan transendensi (tu'minūna billāh).

Ketiga unsur ini menjadi ikon kesejarahan profetik yang digerakkan Kuntowijoyo untuk mencairkan kebuntuan pemikiran umat Islam yang selama ini terjebak dengan rutinitas keberagamaan dan bahkan bermetamorfosa menjadi kekuatan konservatis. Dalam pemikiran Kuntowijoyo, agama disikapi sebagai kesadaran emansipatoris agar bisa menjalankan fungsinya sebagai perubahan sosial atau transformasi masyarakat.

Selain kedua figur intelektual kampus di atas, ada pula sosok sejarawan yang bergelut dalam dunia pemikiran keislaman, yaitu Syafii Ma'arif. Melalui kontribusi pemikiran, Syafii banyak menguraikan tentang kesejarahan al qur'an yang berpihak pada dimensi kemanusiaan dan peradaban. ${ }^{19}$ Bagi Syafii, umat Islam memiliki martabat (muruah) dalam melestarikan kehidupan yang lebih bermakna. Martabat ini bisa diperoleh dengan cara memposisikan diri sebagai orang yang berilmu dan menumbuhkan komitmen (keimanan) kepada nilai-nilai kebaikan, baik kepada Tuhan maupun manusia.

Dengan cara pembahasaan analogis, Syafii mengenengahkan nilai-nilai al qur'an yang mempunyai visi kemajuan dan kesejahteraan manusia. Untuk menggerakkan visi tersebut, tentu umat Islam harus terlibat dalam iklim kebernegaraan agar bisa /menkontribusikan pandangan dan pemikiran dalam setiap proses pembangunan yang dikelola oleh pemerintah. Dengan cara ini, umat Islam menjelma diri sebagai gerakan pembaruan moral yang mengawal setiap kebijakan pemerintah sekaligus mengawasi setiap potensi penyimpangan yang dilakukan oleh setiap pemangku kepentingan dan kekuasaannya.

Ketiga, metode istiṣlāhī yang menggunakan paradigma prospektif-futuristik untuk lebih menekankan nilai-nilai kemaslahatan yang terkandung dalam al-Qur'an maupun Hadis.

${ }^{19}$ Syafii maarif, Membumikan Islam, (Yogyakarta; Pustaka Pelajar, 1995), hlm. 79-86. Baca juga, Syafi'i Ma'arif, Islam Dalam Bingkai Keindonesiaan dan Kemanusiaan: Refleksi Sejarah, (Bandung; Mizan, 2015), hlm. 150-170.
Melalui metode ini, setiap Muslim diarahkan untuk berfikir ke depan dengan cara penjabaran ulang maksud dan tujuan ajaran islam atau yang lebih dikenal sebagai istilah maqāṣid shari'ah yang bisa jadi antara satu waktu masa lalu dengan waktu masa akan datang akan mengalami perbedaan cara pandangan dan pemahaman. ${ }^{20}$

Dalam kaitan ini, salah satu intelektual Muslim yang banyak mengupas dimensi kemaslahatan adalah Masdar Farid Mas'udi' ${ }^{21}$. Dalam pemikirannya, Masdar banyak mengupas dimensi kemaslahatan yang harus dijadikan elan vital dalam keberagamaan. Bahkan, dengan mengutip At Tufi, Masdar menyatakan bila ada benturan pemahaman ( $t a^{\prime}$ ārud) antara dalil agama dengan kemaslahatan, yang lebih dikedepankan adalah kemaslahatan. ${ }^{22}$

Pandangan Masdar ini ingin menegaskan, bahwa kemaslahatan menjadi the ultimate concern yang menafasi setiap dalil nash. Berbagai dalil nash yang membingkai tentang keadilan tak terlepas dari kerangka kemaslahatan yang menjadi hulu gagasannya. Maka, menjabarkan secara kontekstual perihal kemaslahatan yang ada dalam ajaran Islam sembari dipertemukan dengan perkembangan zaman menjadi keniscayaan yang tidak bisa ditolak. Karena di dalam kemaslahatan ada persoalan mendasar terkait dengan bagaimana tanggung jawab agama dalam memelihara lima hal, yaitu memelihara agama itu sendiri (hifz aldin), memelihara jiwa (hifz al-nafs), memelihara akal (hifz al-'aql), memelihara keturunan (hifz al-nasl), memelihara harta (hifz al-māl).23

Secara prospektif, kelima bentuk perlindungan ini bisa dijabarkan secara kontemporer sesuai dengan semangat zamannya. Semisal persoalan agama tidak hanya terkait

${ }^{20}$ Saifudin Zuhri, Ushul Fiqh: Akal Sebagai Sumber Hukum Islam, (Yogyakarta: Pustaka Pelajar, 2009), hlm. 165-175.

${ }^{21}$ Masdar farid Mas'udi, Pajak itu Zakat: Uang Allah Untuk Kemaslahatan Rakyat, (Bandung: Mizan, 2010), hlm. 180-190

${ }^{22}$ Sebagai gambaran perihal pemikiran at-Tufi tentang kemaslahatan baca, Muhammad Roy Purwanto, Dekontruksi Teori Hukum Islam, Kritik Terhadap Konsep Maslahah Najmuddin al-Thufi, (Yogyakarta; Kaukaba, 2014).

${ }^{23}$ Asy-Shatibi, Al-Muawafaqat fi Ushul al-Ahkam, (Beirut: Dar al-Kutub al-Ilmiyyah, t.th.). 
dengan kepemelukan agama yang dimonopoli oleh ummat tertentu, akan tetapi bagaimana agama yang dianut oleh kelompok lain harus dilindungi dan dipelihara melalui tradisi yang berkembang di dalamnya. Demikian pula persoalan jiwa yang berkaitan dengan hak asasi manusia, persoalan akal yang berkaitan dengan kebebasan berfikir, persoalan keturunan yang berkaitan dengan keseimbangan demografis dalam sebuah negara, dan persoalan harta yang berkaitan dengan kedaulatan ekonomi demi terjaganya ketahanan pangan, papan, dan sandang. ${ }^{24}$

Di samping Masdar, terdapat pemikir Muslim handal yang lebih senior dari Masdar. Adalah Gus Dur yang merumuskan gagasan "Pribumisasi Islam" sebagai pengandaian bahwa ajaran Islam tidak selamanya bersifat ilahiyah (qați $)$ melainkan juga bersifat manusiawi (wad'i $)$, selain bersifat universal ia pun bersifat lokal. Maka, berbagai ajaran Islam yang selama ini hanya diakses oleh kelompok muslim tertentu, sehingga banyak nilai-nilai islam yang bernuansa humanitarian tidak diketahui secara masif, dijabarkan ulang oleh Gus Dur sebagai cara berfikir yang merakyat.

Berbagai diksi dan terma keislaman yang selama ini disakralkan oleh kelompok muslim tertentu, dicairkan oleh Gus Dur menjadi sebuah arena interrelasi yang bisa memungkinkan setiap orang mengetahui dan menghayati nilai-nilai keislaman. Penggubahan kalimat “assalamu'alaikum..." menjadi "selamat pagi, siang, dan malam", ujaran "aba" menjadi "bapak" adalah bentuk penganalogian secara kultural yang bisa menggugah kesadaran reflektif setiap orang terhadap keluhuran nilai-nilai keislaman. ${ }^{25}$

Namun, gagasan Gus Dur dianggap bertolak belakang oleh sebagian ummat Islam karena cara berfikirnya berada di luar keumuman pemahaman ummat Islam terutama di level menengah ke bawah. Padahal, apa yang

\footnotetext{
${ }^{24}$ Jasser Auda, Membumikan Hukum Islam Melalui Maqshid Syariah, (Bandung: Mizan, 2015), hlm.178-195

${ }^{25}$ Abdurrahman Wahid, Islam Kosmopolitan: Nilai-nilai Indonesia dan Transformasi Kebudayaan, (Jakarta: The Wahid Institut press, 2007), hlm. 250-260.
}

dilakukan oleh Gus Dur masuk dalam kategori biasa saja yang sebenarnya ingin memperluaskan cara pandang masyarakat terhadap nilai-nilai keislaman yang bisa aksesible dengan aspek kultural. Namun, apa lajur, banyak pihak yang cenderung mengkategorisasikan pemikiran Gus Dur sebagai aliran liberal. Hal ini sebagaimana dilakukan oleh Greg Barton yang meneliti tentang "Gagasan Islam Liberal di Indonesia“" yang objek kajiannya bermuara pada figur Gusdur, dan beberapa pemikiran muslim lain seperti Nurchalis Madjid, dan Ahmad Wahib. ${ }^{26}$

Sebenarnya, apa yang dilakukan oleh Greg Barton dengan memetakan pemikiran Gus Dur dalam wilayah liberalisme bertentangan dengan spirit pandangan Gus Dur yang tidak sepenuhnya liberal. Karena, secara geografis Gus Dur tumbuh besar di lingkungan Pesantrean, pergaulannya berada di lingkungan kyai, dan interrelasi perserikatan ideologinya berada di bawah naungan NU. Bahwa ruh progreisifitas terkadang berkelindan dengan cara berfikirnya dalam merespon persoalan keagamaan yang terkait dengan perilaku sekelompok orang yang melakukan kesalahan yang seringkali mengatasnamakan agama Islam, bukan berarti kedudukan pandangannya direpresentasikan sebagai aliran liberal yang berniat mendekonstruksi bangunan dasar transendental yang ada dalam ajaran Islam. Sebab, walau bagaimana pun posisi Gus Dur adalah seorang kyai yang secara emosional sangat dekat dengan masyarakat bawah, yang karenanya, Gus Dur mempunyai metode istislah untuk/menjabarkan nilai-nilai keislaman yang dikontekstualisasi dengan perkembangan zaman.

Oleh karena itu, sangat penting untuk menegaskan kembali bagaimana metode istislahi cukup berpengaruh dalam peta pemikiran muslim yang berkembang saat ini. Metode ini menjadi lingkup geneanologis untuk mengetahui bagaimana jalur pemiki-

${ }^{26} \mathrm{Greg}$ Barton, Gagasan Islam Liberal di Indonesia: Pemikiran Neo-Modernisme Nurcholis Madjid, Djohan Effendi, Ahmad Wahib dan Abdurrahman Wahid 1968-1980, (Jakarta: Paramadina, 1999), hlm. 450-470. 
ran Islam di Indonesia yang satu sisi menderivasi semangat keislaman dan di sisi lain merespon realitas sosial sebagai titik temu yang saling bersenyawa. Dalam hal ini, penelitian Djohan Efendi ${ }^{27}$ menjadi salah satu rujukan penting yang menegaskan betapa dinamika progresifitas pemikiran Gus Dur dan generasi mudanya tidak dapat disebut sebagai kerangka liberalisme. Sebab, dalam pembaharuan pemikiran tetap terselip kaidah dasar pandangan yang mempertahankan ajaran keislaman yang termanifestasi dalam tradisi keulamaan. Dengan kata lain, adagium "almuhafadzah ala qadimis shalih wal akhdzu bil jadid al aslah" menjadi epistemologi relasional yang menyambungkan antara mereaktualisasi nilai-nilai keislaman dengan rekontekstualisasi nilai-nilai kearifan yang berkembang dalam realitas sosial.

Dengan demikian, penting kiranya melakukan pemetaan ulang terhadap perkembangan khazanah pemikiran Islam di Indonesia yang bisa jadi tidak berkaitan dengan asumsi "liberalisme" namun justru berkaitan dengan paradigma interkoneksi dalam mengembangkan ajaran Islam yang lebih kontekstual.

Kehadiran Gusdur dalam blantika pemikiran Islam di Indonesia, melengkapi beberapa seniornya yang telah lama mengontribukasikan pemikirannya bagi kemaslahatan rakyat Indonesia. Di antaranya adalah KH. Ali-Yafie yang sangat kompeten di bidang pemikiran keislaman. Keberadaan Ali Yafie disebut sebagai pemikir muslim yang modern karena berhasil mengkontekstualisasi kajian keislaman yang nota bene berkaitan dengan ilmu kesyariahan ke dalam pemikiran fikih sosial. ${ }^{28}$

Dalam pemikiran fikih sosial, Ali Yafie banyak menjabarkan konsep-konsep kemaslahatan yang diselaraskan dengan perkembangan zaman. Berbagai diktum hukum Islam yang dikenal dengan sebutan al ahkam al khamsah seperti-wajib (fardlu),

${ }^{27}$ Johan Efendi, Pembaharuan Tanpa Membongkar Tradisi, (Jakarta: Kompas, 2010), hlm. 76.

${ }^{28} \mathrm{R}$. Michael Feener, Muslim Legal Thought in Modern Indonesia, (USA: Cambridge University Press, 2007). sunah (mandub), haram, makruh, dan boleh (mubah)-perlu dimanifestsi dalam keseharian yang berkaitan dengan urusan keduniaan pula. Salah satu contoh penjabaran diktum wajib (fardlu) yang terdiri dari wajib personal ('ain) dan kolektif (kifayah) tidak hanya dikaitkan dengan wilayah ibadah mahdlah. Melainkan urusan public (mu'amalah) perlu dilandasi kesadaran transcendental yang meniscayakan pemberian prestasi atas kinerja baiknya yang tidak semata berbentuk reward keduniawian, juga dalam bentuk pahala keakhiratan (ukhrāwiyyah). ${ }^{29}$

Setidaknya, melalui penjabaran kelima dictum secara kontekstual, memungkinkan setiap orang yang giat bekerja, melaksanakan tugas, serta bertanggung jawab atas tugas yang dihadapi serta menghindari setiap perbuatan yang bertentangan dengan aturan yang berlaku dalam tugas kesehariannya. Bahkan dalam konteks kebangsaan, Ali Yafie mempertemukan konsep fikih sosial ke dalam konsep pembangunan yang menjadi landasan kebijakan pembanguan pemerintah. Konsep pemikiran Ali Yafie menjadi strategi pemaknaan sosial ajaran Islam sebagai landasan untuk mendukung setiap program pemerintah serta pewacanaan kebijakan pemeirntah melalui terma-terma ajaran Islam agar mudah diterima oleh masyarakat. Hal ini, tentu sepanjang kebijakan pemerintah tersebut berdampak kepada kemaslahatanyang menjadi/spirit ajaran Islam-maupun kesejahteraan-yang menjadi spirit UUD 45 sebagai dasar konstitusi negara. ${ }^{30}$

Dengan demikian, konsep kemaslahatan yang dielaborasi dalam pemikiran fikih sosial Ali Yafie menjadi salah satu motor pendukung untuk mewujudkan cita-cita UUD 45 untuk menciptakan manusia seutuhnya-yang dalam bahasa agama dikenal sebagai "insān kāmil". Di samping KH. Ali Yafie, ada ulama lain yang concern di bidang pemikiran keislaman yang menderivasikan konsep pemikiran fikih

${ }^{29} \mathrm{KH}$. Ali Yafie, Menggagas Fikih Sosial, (Bandung: Mizan, 1994), hlm. 89-95.

${ }^{30}$ Fathorrahman dalam disertasi berjudul Konsep Pemikiran Fikih Sosial KH. Ali yafie" (Disertasi 2015). 
sosial dalam lingkup kultural. Sosok KH. Sahal Mahfudz yang sangat berpengaruh di kalangan komunitas NU, mempunyai konsep yang sama dengan KH. Ali Yafie.

Perbedaannnya, bila KH. Ali Yafie menjabarkan konsep kemaslahatan dalam pemikiran fikih sosialnya dalam lingkup strutkturalkepemerintahan, di mana sasaran bidiknya adalah pelestarian pembangunan yang diharapkan bisa memberikan kemanfaatan bagi seluruh rakyat Indonesia, sedangkan $\mathrm{KH}$. Sahal Mahfudz banyak menjabarkan konsep kemaslahatan dalam pemikiran fikih sosialnya dalam lingkup cultural-kemasyarakatan, di mana sasaran bidiknya adalah semangat pemberdayaan yang bisa memberikan keuntungan bagi masyarakat menengah ke bawah. ${ }^{31}$

Dalam kaitan ini, untuk menunjang proses indoktrinasi keislaman yang berkaitan dengan pemikiran fikih sosialnya, KH. Sahal Mahfudz menggunakan strategi pemaknaan sosial terhadap bangunan ajaran yang terdapat dalam dalil-dalil nash. Dalam pemaknaan sosial ini, ada lima unsur yang ditegaskan oleh KH. Sahal Mahfudz, yaitu pertama, interpretasi teksteks fikih secara kontekstual. Kedua, perubahan pola bermazhab dari bermazab secara tekstual (madhab qawlī) ke bermazhab secara metodologis (madhab manhaji). Ketiga, verifikasi mendasar mana ajaran yang pokok (ușūl) dan mana yang cabang (furū'). Keempat, fikih dihadirkan sebagai etika sosial, bukan hukum positif negara. Kelima, pengenalan metodologi pemikiran filosofis, terutama dalam masalah budaya dan sosial. ${ }^{32}$ Kelima unsur pemaknaan sosial ini menjadi kerangka konseptual yang memungkinkan metode istislahi bisa mewarnai di setiap pemahaman keislamannya. Sehingga, ajaran Islam yang secara fundamental bermuara kepada spirit "rahmatan lil 'ālamin"” bisa terimplementasi dengan baik.

Ketiga metode ini-yang merujuk pada epistemologi fiqhiyyah untuk menjelaskan peta pergerakan umat Islam baik secara per-

${ }^{31}$ Zubaidi Fikih Sosial Kyai Sahal Mahfudz: Perubahan Nilai Pesantren dalam Pengembangan Masyarakat (Disertasi).

${ }^{32}$ KH. Sahal Mahfudz, Nuansa Fikih Sosial, (Yogyakarta; LKiS, 2012), hlm. 280-285. sonal maupun institusional-menjadi sebuah dinamika pemikiran yang tidak banyak dicermati oleh banyak peneliti baik di kalangan intelektual Indonesia maupun Luar Negeri. Padahal, mengkaji dinamika pemikiran Islam di Indonesia tidak bisa lepas dari model pembacaan ajaran Islam yang bersumber dari fikih. Bahkan, dari saking pentingnya kajian fikih, Abid Al Jabiri mengatakan bahwa fikih menjadi jantung peradaban keilmuan Islam yang tidak bisa dilepaskan dari kerangka berfikir umat Islam itu sendiri. Apalagi, dalam model produksi pemikiran keislaman yang digandrungi oleh kaum intelektual selalu mengacu kepada sumber-sumber naqliyyahseperti al-Qur'an dan Hadis-yang alat analisis pemahamannya selalu beranjak dari kacamata fikih.

Maka, menjadi penting penggunaan epistemologi fikih sebagai metode dan pendekatan dalam menganalisis dinamika pemikiran keislaman yang berlangsung di Indonesia. Setidaknya, melalui kerangka ber-fikih, masyarakat bisa memahami mengapa banyak umat Islam yang menggantungkan keputusan kepada ketentuan fikih sebagai basis perilaku kesehariannya? Mengapa produk pemikiran keislaman di Indonesia mengalami perubahan dan perkembangan baik secara progresif maupun regresif?

Dengan demikian, perihal dinamika yang basis pergerakannya mengacu kepada perubahan kondisi yang silih berganti bersenyawa dengan karakteristik fikih yang ciri keilmuannya menjadi tonggak pemahaman keislaman untuk mengkaji perjalanan dinamika pemikiran Islam di Indonesia.

\section{DINAMIKA PEMIKIRAN ISLAM MENUJU SPIRIT KEBANGSAAN DAN KEINDONESIAAN}

Beberapa tahun Greag Fealy mengkaji perubahan cara pandang NU yang semula berkutat dalam lembaga yang konservatif, berorientasi ke dalam dan berkonsentrasi pada kegiatan sosial keagamaan berubah dan berkembang menjadi organisasi yang bercabang-cabang, berorientasi pada dan giat dalam politik, dan 
dengan aspirasi utama mencari peran penting dalam urusan nasional pasca kemerdekaan. ${ }^{33}$

Demikian pula hasil penelitian disertasi Bahtiar Efendi ${ }^{34}$ mengelaborasi model intelektualisme Islam ke dalam tiga aliran yang berkisar pada wilayah, pertama, pembaruan teologis atau keagamaan yang berkaitan dengan fenomena generasi Muslim yang menjadikan produk pemahaman umat Islam atas dokrin keagamaan sebagai landasan untuk membentuk pemikiran dan praktik politiknya. Hal ini sebagaimana tampak dalam berbagai gerakan intelektual kampus seperti HMI, PII, GPII (Gerakan Pemuda Islam Indonesia, dan Persami (Persatuan Sarjana Muslim Indonesia).

Kedua, reformasi politik atau birokrasi yang diawali dengan keterlibatan aktivis politik Islam untuk memainkan peran penting dalam proses pemerintahan dan pembuatan kebijakan di Indonesia. Hal ini perlu dilakukan agar terjalin hubungan sinergis antara pemimpin dan aktivis Islam politik dengan lembaga-lembaga politik maupun birokrasi yang ada agar bisa melakukan perubahan dari dalam. Ketiga, transformasi sosial yang berbasis kepada tiga unsur seperti: (a) upaya memperluas makna politik yang berhubungan program pemberdayaan masyarakat (politik kerakyatan) dan bukan demi kepentingan (politik kekuasaan). (b) memupuk hubungan yang lebih bermanfaat antara negara dan organisasi kemasyarakatan. (c.) merumuskan dan mendefinisikan cota-cita politik Islam yang berwatak inklusif yang bisa mensintesiskan dimensi keislaman dan keindonesiaan..$^{35}$

Dua kajian akademik di atas menjadi contoh adanya dinamika pemikiran yang tumbuh di dalam tubuh umat Islam yang mengarah pada spirit kebangsaan dan keindonesiaan. Berbagai upaya kerja intelektual yang dilakukan oleh kelompok pergerakan baik di level organisasi keagamaan maupun organisasi kemahasiswaan

\footnotetext{
${ }^{33}$ Greag Fealy, Ijtihad Politik Ulama: Sejarah NU 1952-1967, (Yogyakarta: LKiS, 2003), hlm. 230-250.

${ }^{34}$ Bahtiar Efendi, Islam dan Negara: Transformasi Pemikiran dan Praktik Politik Islam di Indonesia, (Jakarta: Paramadina, 1998), hlm. 360-400.

${ }^{35}$ Bahtiar Efendi, Islam dan Negara.,hlm.360-400.
}

membersitkan sebuah cita-cita besar bahwa sejatinya pemikiran Islam yang perlu tumbuh di Indonesia adalah yang berorientasi kepada pemikiran yang berdimensi kemaslahatan. Sebab, secara fundamental, kehadiran Islam di muka bumi ini adalah untuk memberikan rahmat bagi seluruh alam.

Untuk merealisasikan cita-cita besar Islam tersebut, tentu membutukan perangkat kerja sosial yang bersifat empiris dan bisa dijangkau oleh semua orang. Dalam kaitan ini, politik menjadi sarana (wașilah) yang efektif untuk memanifestasikan nilai-nilai keislaman. Sebab, tanpa politik ajaran Islam yang menjadi pesan ketuhanan dan kenabian tidak akan pernah bisa dikenali dan difahami sebagai amal shalih yang meniscayakan kebenaran dan keadilan sepanjang zaman (șālihun fi kulli zamān wa makān). Maka, dalam khazanah keilmuan Islam terdapat sebuah epistemologi pengetahuan berupa fikih yang mendedahkan kanalisasi penjabaran secara teknis dan administratif tentang nilai-nilai keislaman.

Secara sistemik, fikih membukakan berbagai pintu metodologi dan pendekatan untuk menggali beragam kearifan dan keterbukaan yang ada dalam Islam. Hal ini penting diperhatikan, agar Islam yang tidak sekedar menjadi konstruksi keberagamaan melainkan juga menjadi konstruksi pemikiran ${ }^{36}$ bisa menjadi jalan pembuka untuk menjabarkan dan memperluas berbagai maksud dan tujuan yang ada dalam shari'ah (maqāṣid sharīah) yang menjadi salah satu inti ajaran Islam.

Oleh karena itu, menapaki berbagai ruas pemikiran Islam yang berlangsung dinamis di tubuh pemeluknya-melalui epistemologi fikih-menjadi cara tersendiri untuk mengenali dari dalam tentang berbagai upaya yang dilakukan oleh pelakunya-baik secara personal maupun institusionalyang dimungkinkan bisa berkontribusi bagi penguatan dan peneguhan sendi-sendi kebangsaan dan keindonesiaan.

${ }^{36}$ Abis al-Jabiri, Formasi Nalar Arab: Kritik Tradisi dan Wacana Agama, (Yogyakarta; Ircisod, 2014), hlm. 350-360. 
Dalam kaitan ini, tiga metode epistemologi fikih yang dijabarkan di atas menjadi pendekatan sosiologis untuk menjelaskan bagaimana nalar bayānī, nalar isti'tālì, dan nalar istiṣlāhì dimainkan sebagai arena representasi oleh beberapa pelaku yang terlibat dalam mengusung paham keberagamaannya.

Nalar bayānī yang banyak diadopsi oleh kelompok-kelompok "kanan" semisal PKS yang selalu berupaya mengedepankan nilainilai keislaman-yang secara ideologis bertaut kelindan dengan organisasi keagamaan seperti HTI maupun Majelis Mujahidin-sebagai landasan prinsipil bernegara di Indonesia. Pengalaman politik seperti yang dilakukan oleh SI pada masa sebelum kemerdekaan dijadikan inspirasi oleh PKS untuk mengonsolidasikan pergerakannya guna mencapai sebuah cita-cita sebagaiman pernah terlansir dalam Piagam Jakarta.

Meski upaya "Islamisasi" yang kerap diperjuangkan PKS selalu berbenturan kelompok mainstream lain yang justru lebih mengedepankan semangat kebangsaan yang universal, kelompok-kelompok underbouw PKS tetap rajin mengerangkai gerakan massanya melalui kegiatan halaqoh bernuansa islamisme yang marak berlangsung di kampus-kampus umum.

Pada saatnya, bila kelompok mainstream abai dengan komitmen kebangsaannya dan sibuk membingkai ruang kontestasi untuk merebut kekuasaan secara pragmatis, bisal jadi gerakan massa di bawah kendali PKS akan hadir sebagai vote getter yang mendulang dukungan dari berbagai kalangan masyarakat yang selama ini dibiarkan dan tidak diperhatikan.

Berbeda dengan nalar bayani yang banyak direaktualisasi sebagai mekanisme pengetahuan dan pergerakan untuk menegakkan semangat keislaman di Indonesia, pada kelompok lain yang menggunakan nalar isti'lālī menunjukkan performa berbeda dengan cara tidak mengentarai arus pemikiran dan pergerakkannya dalam skop Islamisme.

Nalar isti'lālī menjadi ruang kristalisasi pemikiran sebagai bangunan analogis antara ajaran keagamaan dengan realitas sosial yang terjadi. Dalam nalar ini, spirit kekinian (kontekstual) menjadi kelaziman untuk diadaptasi sebagai cara pandang kontemporer untuk membingkai nilai-nilai substansial yang ada dalam agama dan diselaraskan dengan semangat kebangsaan.

Sebuah pemikiran yang diajukan Amien Rais seperti politik Adiluhung (high politics) yang menjabarkan nilai-nilai ketauhidan (tauhidic values) membingkai sebuah cara pandang tentang kejujuran, keikhlasan, amanah, dan ukhuwah yang harus dimanifestasi dalam semangat kebangsaan. ${ }^{37}$ Corak keindonesiaan yang tidak lepas dari iklim ketimuran perlu mengkerangkai asas kebernegaraannya melalui khazanah pemikiran yang satu sisi mengadopsi pengalaman kenusantaraan dan di sisi memanifestasikan pengetahuan keagamaan, terutama pada tataran substansial. Dengan harapan, setiap pemangku kekuasaan yang digerakkan melalui roda kepemerintahan tidak terjebak pada penumpukan kepentingan yang hanya menguntungkan pihak tertentu, sementara pihak kebanyak dijebak dalam suasana kebuntungan.

Senafas dengan pemikiran Amien Rais, kehadiran Kuntowijoyo dalam blantika pemikiran keislaman di Indonesia turut berkontribusi dalam menyegarkan pandanganpandangan keagamaan yang bernuansa kritisinterpretatif. Berbagai dalil agama yang bersumber dari al-Qur'an dan Hadis difahami sebagai konstruksi gagasan yang perlu diterjemahkan ulang berdasarkan etos zaman yang berlaku dalam kehidupan masyarakat. ${ }^{38}$

Oleh karena itu, dogma "amar ma'rūf, nahy munkar, dan tu'minu billāh" yang tersirat dalam salah satu surat al-Qur'an dipahami Kuntowijoyo sebagai landasan pergerakan yang satu sisi berdimensi kemanusiaan dan di sisi lain berdimensi ketuhanan. amar ma'rūf yang berarti humanisasi, nahy munkar yang berarti liberasi, dan tu'minu billāh yang berarti transendensi adalan trianggulasi pemikiran

\footnotetext{
${ }^{37}$ Amien Rais, Cakrawal Pemikiran., hlm. 76.

${ }^{38}$ Kuntowijoyo, Paradigma Islam., hlm. 98.
} 
yang antara satu dengan lainnya saling berjalin kelindan.

Bila Pemikiran Kuntowijoyo ini dikontekstualisasi dalam ranah kebangsaan dan keindonesiaan, maka seruan moral yang ditegaskan Kuntowijoyo adalah, bagaimana program pemberdayaan kepemerintahan bisa berdampak kepada pembangunan yang dilandasi semangat kemanusiaan secara berkelanjutan, bagaimana program penegakan peraturan bisa berdampak pada pembebasan rakyat dari jebakan kejahatan, dan bagaimana merumuskan sistem perencanaan dan pelaksanaan kebijakan pemerintah dilandasi oleh komitmen kepatuhan dan ketaatan yang diniati oleh semangat pengabdian-yang dalam bahasa agama disebut sebagai ibadah.

Adapun nalar istiṣlāhī membangun corak tersendiri ihwal bagaimana membangun cara berfikir prospektif melalui penggubahan ajaran keagamaan yang adequate di setiap peralihan ruang dan zaman. Dalam nalar istișlāhì, terdapat corak perbandingan (muqāranah) antara ajaran keagamaan dengan spirit kebangsaan yang dileburkan dalam tantangan keber-Indonesiaan.

Cara pandang kemaslahatan yang ditegaskan dalam nalar istișlāhīini menggubah gugusan pengalaman dan pengetahuan keberagamaan yang terkadang dianggap memadai di masa lalu namun terkadang bertolak belakang dengan masa kini. Lebih-lebih bila dihadapkan dengan tantangan masa depan, di mana karakteristik kehidupan akan mengalami perubahan yang sesuai dengan semangat zamannya.

Maka, corak perbandingan yang dikedepankan dalam nalar istișlāḥi dirumuskan melalui fikih prioritas (figh al-awwaliyāt) untuk menemukan benang merah kesesuaian antara esensi ajaran dengan substansi persoalan yang terjadi. Semisal, sikap kita dalam memperlakukan negara di ruang publik yang di saat bersamaan terkadang sebagian kita menuntut termanifestasinya nilai-nilai keagamaan secara lebih unggul dari pada nilainilai negara? Apakah benar menjaga agama (hifz al-dīn)-yang dalam terma maqāṣid sharīah masuk dalam kategori darūriyyah-lebih penting dari pada menjaga negara (hifz aldawlah) yang di saat bersamaan justru negara membutuhkan kesadaran dan tindakan kolektif agar terhindar dari ancaman keamanan? Benarkah menjunjung tinggi semangat keberagamaan lebih penting manakala proses yang dibangun seringkali menggoncang keutuhan dan kerukunan berbangsa?

Beberapa pertanyaan di atas menjadi titik pijak pemikiran dalam nalar istiṣlāhī untuk menentukan sebuah sikap opsional yang memberikan dampak kemaslahatan yang lebih besar. Melalui kaidah fikih "akhaffu darūrayni", nalar istișlāhi -sebagaimana yang terurai dalam pemikiran Masdar Farid Mas'ud, KH. Salah Mahfud, dan KH. Ali Yafie mencoba menjelaskan kepada publik, bahwa dalam sebuah negara yang heterogen, semua latar kelompok harus tunduk dalam satu ideologi kebangsaan yang bisa diakui bersama.

Oleh karena itu, nalar istiṣlāhi yang digunakan beberapa figur tersebut sangat mempertimbangkan betul bila terkadang ada desakan dari sekelompok umat Islam yang berupaya menolak Pancasilan sebagai dasar negara Indonesia, lebih mempercayai sistem shari'ah sebagai landasan konstitusional di banding UUD 45, hingga penegasan khilafah sebagai sistem kepemerintahan yang dianggap ideal dibanding demokrasi yang sudah disepakati dalam coraknegara bangsa (nation state) di era modern.

Sebab, dalam nalar/istișlāhī, sejatinya negara perlu dipersepsikan sebagai induk utama kehidupan berbangsa di mana semua kelompok yang terdiri dari berbagai latar belakang yang berbeda memiliki akses rerata untuk memperoleh berbagai fasilitas yang ada di dalamnya. Negara perlu diyakini sebagai ibu pertiwi bagi semua golongan yang dengan kearifannya dapat membesarkan semua pihak menjadi warga yang baik.

Sementara agama adalah salah satu varian yang membukakan jalan menuju kerahmatan, kearifan, dan kemaslahatan/kesejahteraan yang dicita-citakan negara. Dan kalau pun aga- 
ma dianggap sebagai penopang penting bagi keberlangsungan negara, sejatinya agama bisa menjadi energi metafisik dan spritualitas untuk melakukan pengkayaan dan perluasan simbolisasi dan konsolidasi kebangsaan yang bisa diinsafi oleh semua warga negara.

Nalar istișlāhì menegaskan sebuah slogan "hubbul watan min al-īmān (menaruh perhatian simpatik kepada negara) sebagai pembacaan progresif untuk memperlakukan negara dengan baik melalui partisipasi kita sebagai warga yang bisa berbaur dengan kelompok yang berbeda aliran dan kepercayaan. Dengan cara demikian, apa yang menjadi harapkan bersama terhadap negara agar hukum bisa tegak dengan adil dan benar, lestarinya lingkungan dengan asri, meratanya ekonomi dengan proporsional, terjaganya warisan kebudayaan dengan baik, terbukanya ruang politik kekuasaan secara bertanggung jawab, terbangunnya keamanan dan ketahanan nasional, dan lain sebagainya akan menjadi kenyataan.

Dengan catatan, kita bisa memperlakukan negara dengan cara pandang prioritas di mana agama menjadi adalah salah satu simpul penggerak sistem sosial kebangsaan dalam kehidupan bermasyarakat yang berlandaskan nilai-nilai luhur seperti toleransi (tasāmuh), moderasi (tawāṣuț), keseimbangan (tawāzun), dan keadilan (ta'ādul).

Dalam konteks ini, nalar istișlāhì merangsang perubahan cara pandang kita tentang corak keberagamaan däri seekadar mengkerangkai nalar bayani yang selalu mendaur ulang kedigdayaan masa lalu maupun nalar isti'lāli yang nuansanya hanya menegaskan kepentingan masa sekarang. Sebab, kehidupan manusia akan berubah dan secara otomatis akan berpengaruh terhadap corak kebernegaraan kita, di mana Indonesia akan berhadapan dengan aneka ragam tantangan.

Maka, nalar istiṣlāḥi mengkerangkai sebuah pemikiran perbandingan antara masa lalu dan masa kini untuk dikonstruksi sebagai modal sosial dalam menyiapkan pemikiran yang memadai untuk masa akan datang. Dalam kaitan ini, meneguhkan semangat kebangsaan dan keindonesiaan adalah lebih penting untuk diutamakan dari pada menegaskan ajaran keagamaan yang interrelasi kuasanya berkutat pada dimensi keummatan secara monolitik.

\section{KESIMPULAN}

Membaca peta pemikiran Islam Indonesia yang berlangsung secara dinamis dan bahkan dialektis sejak pra kemerdekaan, pasca kemerdekaan, hingga era Reformasi menyiratkan berbagai ragam pergolakan di tubuh umat Islam. Beberapa pelaku pemikiran Islam yang terlibat di ruang-ruang pergerakan sosial dan pergerakan keagamaan, menjadi simpul penggerak sebuah wacana dan perbenturan pandangan yang menyeruak ke permukaan.

Perbedaan cara pandang antar simpul penggerak tersebut dilatari oleh pengalaman pendidikan, pengalaman organisasi, dan dialektika pengetahuan yang tumbuh dalam suasana pergerakannya. Semisal nalar bayānī yang banyak dimanifestasikan kelompok kanan seperti PKS dan relasi kuasanya dengan corak tesktualis-fundamentalistik, tidak lepas dari atmosper pergerakannya yang memang banyak mentransformasi berbagai refrensi pemikiran yang beraliran kanan, seperti Ikhwanul Muslimin dan Pan Islamisme ke dalam kajian wacananya dan penguatan cara berfikirnya.

Menjadi wajar bisa produksi pengetahuan keberagamaannya berlangsung secara eksklusif yang nyaris bertolak belakang dengan arus mainstream di Indonesia yang lebih menghendaki suasana terbuka dan pembauran antara satu kelompok atau aliran yang lainnya. Bahkan, melalui nalar bayānī yang direproduksi sebagai pendekatan dan metode pergerakan, mereka memperjuangkan prinsip-prinsip keislaman yang diyakini dengan berupa mengajukan perubahan dasar negara, landasan konstitusi, dan sistem kepemerintahan. Uniknya, perjuangan mereka kian masif ketika angin reformasi memberikan ruang gerak kebebasan bagi setiap kelompok untuk mengekspresikan pandangan dan 
pemikirannya. Seolah menemukan ruang memadainya, kelompok-kelompok kanan kian rajin mengembang-biakkan nalar bayānī sebagai landasan embrional bagi kelahiran varian gerakan fundamentalistik untuk selalu memperjuangkan semangat keislaman.

Adapun nalar isti'lālì yang banyak digerakkan oleh kelompok modernis seperti Muhammadiyah memanifestasikan pemahaman dan penafsiran berbeda ihwal semangat keagamaan di ruang publik. Melalui konstruksi pemikiran substantifnya, kelompok ini banyak mengarahkan model pembacaan yang kontekstual terhadap berbagai al-Qur'an dan Hadis yang menjadi sumber ajaran Islam.

Dalam nalar isti'lālì ini, ajaran keagamaan dipertautkan dengan pengalaman kesejarahan yang berlangsung dalam kehidupan masyarakat Indonesia. Di mana, latar belakang rakyat Indonesia yang terdiri dari beragam suku, ras, dan agama perlu dijadikan sebagai meniatur perbedaan (ikhtilaf) yang saling mengisi dan menerima berbagai ajaran sosial yang dianut.

Dengan corak demikian, kelompok modernis yang banyak berada di bawah naungan Muhammadiyah, melakukan eksperimentasi kajian keindonesiaan melalui pemikiran ulang (re-thingking) tentang konsep keberagamaan yang kontekstual di ruang publik. Sehingga, banyak pemikiran kritis yang lahir dari kelompok ini sembari mengajukan bentu analogisme baru tentang Swawasan keberagamaan dan wawasan kebangsaan.

Sedangkan nalar istișlāhî yang banyak dige-rakkan kelompok tradisionalis yang berada di bawahnaunganNU mengembangkan pemikiran keislaman yang bercorak prospektif-futuristik yang spirit utamanya adalah bagaimana membangun jembatan pemikiran keislaman yang tidak hanya selaras dengan tuntutan zaman yang terjadi secara temporer dan masa kini, melainkan bisa bermanfaat bagi generasi masa akan datang.

Penggubahan ajaran Islam yang diurai dalam fikih-selain al-Qur'an dan Hadis-oleh pemikir Muslim yang berbasis pada aliran neo tradisionalisme, dimaksudkan untuk meru- muskan formula masa depan dengan konsep kemaslahatan. dalam hal ini, konsep kemaslahatan yang menjadi sistem sosial yang tak terikat oleh ruang dan waktu, dimungkinkan bisa diterima oleh berbagai generasi. Sebab, pernik-pernik pemikiran keislaman yang dibangun keempat orang di atas-yang oleh generasi muda NU dianggap sebagai peletak dasar pemikiran keislaman ala NU-akan menjadi semacam korpus terbuka yang bisa diakses oleh berbagai kalangan.

Secara prinsipil, ketiga nalar (bayānī, isti'lālì, dan istiṣlāhì) yang bergerak dalam bingkai epistemologi fikih akan menjadi dokumen sejarah pemikiran Islam di Indonesia yang pada suatu masa akan dianggap penting sebagai dasar pemahaman dan penelaahan bangunan pemikiran Islam dari masa ke masa.

Maka, tantangan ke depan adalah, untuk memahami peta pemikiran Islam Indonesia di masa akan datang, semestinya berangkat dari konstelasi konseptual yang berkaitan dengan khazanah kajian yang lekat dengan geografi masing-masing pelakunya. Dalam konteks ini, sangat penting menggunakan kerangka epistemologi fighiyyah sebagai pendekatan eksplorasi corak pemikiran yang dilakukan oleh setiap figur Muslim.

Setidaknya, epistemologi fiqhiyyah menjadi landasan definisi operasional untuk menjabarkan beragam motivasi dan arah pemikiran yang dilakukan/oleh umat Islam dalam memahami dan menafsirkan berbagai dalil naqliyah seperti al-Qur'an dan Hadis yang diyakini sebagai main resources oleh umat Islam melalui pendekatan kontekstual.

Dengan cara demikian, maka berbagai rumusan kajian yang mengeksplorasi peta dan kecendrungan pemikiran Islam di Indonesia akan mewakili representasi identitasnya sebagai bangsa yang bermental menengah (wașatiyyah). Meskipun di sisi lain ada kecendrungan radikal dalam cara berfikir umat Islam tertentu, bukan berarti hal tersebut dianggap mewakili sebagian umat Islam lain yang satu sisi menggunakan ajaran Islam sebagai nalar berfikir untuk mengkon- 
tekstualisasi nilai-nilai ketuhanan dan kenabian. Di samping itu, tidak tepat pula untuk mengkerangkai cara berfikir umat Islam yang lain yang banyak mengggunakan pendekatan sosial-kritis dalam memahami dan menafsirkan al-Qur'an sebagai kelompok liberal yang saat ini sedang mengalami kerentanan identitas di tubuh umat Islam.

Maka, merumuskan epistemologi fighiyyah sebagai kerangka pemetaan pemikiran Islam Indonesia menjadi pintu masuk untuk mengetahui lebih mendalam bagaimana motivasi dan arah umat Islam dalam membingkai persoalan kontemporer, merespon perubahan sosial dan perkembangan zaman, serta menyikapi era globalisasi yang ditandai dengan kultur kemodernan yang melansir konsep pembangunan dan pemberdayaan.

Ini lah sekilas pandangan bagaimana tantangan dan peran umat Islam dalam memposisikan dirinya sebagai kelompok muslim yang terlibat dalam praktik pewacanan ajaran keislaman di ruang publik sekaligus posisi peran serta dalam peneguhan semangat kebangsaan dan keindonesiaan.[]

\section{DAFTAR PUSTAKA}

Afandi, Arif, Islam Demokrasi Atas Bawah: Polemik Strategi Perjuangan Umat Model Gus Dur dan Amien Rais, Yogyakarta: Pustaka Pelajar, 1997.

Auda, Jasser, Membumikan Hukum Istam Melalui Maqshid Syariah, Bandung: Mizan, 2015.

Aziz, Ahmad Amir, Neo-Modernisme Islam Di Indonesia, Jakarta: Rineka Cipta, 2000.

Barton, Greg, Gagasan Islam Liberal di Indonesia: pemikiran neo-modernisme Nurcholis Madjid, Djohan Effendi, Ahmad Wahib dan Abdurrahman Wahid 1968-1980, Jakarta: Paramadina, 1999.

Efendi, Johan, Pembaharuan Tanpa Membongkar Tradisi, Jakarta: Kompas, 2010.
Efendi, Bahtiar, Islam dan Negara: Transformasi Pemikiran dan Praktik Politik Islam di Indonesia, Jakarta: Paramadina, 1998.

Fathorrahman, Konsep Pemikiran Fikih Sosial KH. Ali Yafie, Disertasi 2015

Feener, R. Michael, Muslim Legal Thought in Modern Indonesia, USA: Cambridge University Press, 2007.

Fealy, Greag, Ijtihad Politik Ulama: Sejarah NU 1952-1967, Yogyakarta: LKiS, 2003.

Hamidi, Jazimermeneutika Hukum, Teori Penemuan Hukum Baru Dengan Interprestasi Teks, Yogyakarta : UII Pres, 2004.

Hasan, Noorhaidi, Islam Politik di Dunia Kontemporer: Konsep, Geneologi, dan Teori, Yogyakarta: Suka Press, 2012.

Husaini, Adian dan Nuim Hidayat, Islam Liberal: Sejarah, Konsepsi, Penyimpangan dan Jawabannya, Yogyakarta: GIP, 2002.

Al-Jabiri, Abed, Formasi Nalar Arab: Kritik Tradisi dan Wacana Agama, Yogyakarta; Ircisod, 2014.

Kuntowijoyo, Paradigma Islam: Interpretasi untuk Aksi, Bandung: Mizan, 1994.

, Identitas Politik Umat Islam, Bandung: Mizan, 1997. , Dinamika Sejarah Umat Islam Indonesia, Yogyakarta: Pustaka Pelajar, 1994.

Latif, Yudi, Negara Paripurna: Historisitas, Rasionalitas dan Aktualitas Pancasila, Jakarta: Gramedia, 2011.

-.--, Intelegensia Muslim dan Kuasa, Bandung: Mizan, 2003.

Maarif, Syafii, Membumikan Islam, Yogyakarta; Pustaka Pelajar, 1995.

dan Kemanusiaan: Refleksi Sejarah, Bandung; Mizan, 2015.

Mahfudz, KH. Sahal, Nuansa Fikih Sosial, Yogyakarta; LKiS, 2012. 
Mas'udi, Masdar Farid, Pajak itu Zakat: Uang Allah Untuk Kemaslahatan Rakyat, Bandung: Mizan, 2010.

Nashir, Haedar, Islam Syariat: Reproduksi Salafiyah Ideologis di Indonesia, Bandung: Mizan, 2013.

Noer, Deliar, Gerakan Modern Islam di Indonesia 1900-1942, Jakarta: LP3ES, 1980.

Purwanto, Muhammad Roy, Dekontruksi Teori Hukum Islam, Kritik Terhadap Konsep Maslahah Najmuddin Al-Thufi, Yogyakarta; Kaukaba, 2014.

Rahman, Asjmuni A., Metode Penetapan Hukum Islam, Jakarta; Bulan Bintang, 2004.

Rais, Amien, Cakrawala Islam: Antara Cita dan Fakta, Bandung: Mizan, 1987.

Saifudin, Khilafah vis a vis Nation State: Telaah atas Pemikiran HTI, Thesis pada program Pascasarjana UIN Sunan Kalijaga.

Shodiq, Abdulloh, Sekulerisme Soekarno dan Mustafa Kemal, Pasuruan: PT. Garoeda Buana Indah, 1994.

Al-Shatibi, Al-Muawafaqat fi Ushul al-Ahkam, Beirut: Dar al-Kutub al-Ilmiyyah, t.th.
Sitompul, Einar Martahan, NU dan Pancasila, Yogyakarta: LKiS, 2010.

Suradi SS, Grand Old Man of The Republic Haji Agus Salim dan Konflik Politik Dalam Sarekat Islam, Yogyakarta: Mata padi presindo, 2014.

Syarifuddin, Amir, Ushul Fiqih, Jakarta; PT. Logos Wacana Ilmu, 1997.

Wahid, Abdurrahman, Islam Kosmopolitan: Nilainilai Indonesia dan Transformasi Kebudayaan, Jakarta: The Wahid Institut Press, 2007.

Yafie, KH. Ali, Menggagas Fikih Sosial, Bandung: Mizan, 1994.

Zubaidi, Fikih Sosial Kyai Sahal Mahfudz: Perubahan Nilai Pesantren dalam Pengembangan Masyarakat. Disertasi

Zuhri, Saifudin, Majelis Tafsir Al Qur'an and its struggle for Islamic reformation, Thesis pada Leiden University.

Zuhri, Saifudin, Ushul Figh: Akal Sebagai Sumber Hukum Islam, Yogyakarta: Pustaka Pelajar, 2009.

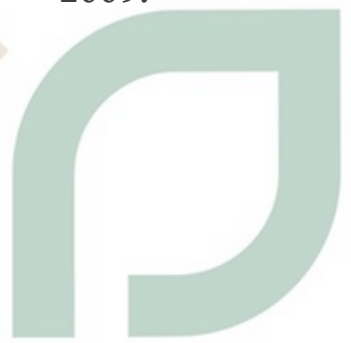

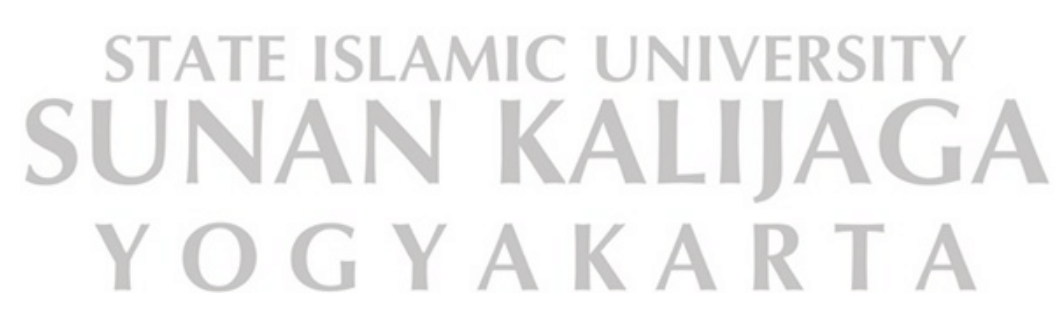

